\title{
DETERMINATION OF CHLORINE ON BREWED ROBUSTA COFFEE (Coffea canephora var. Robusta) WITH V60 METHOD
}

\author{
Irma Rahmawati ${ }^{\star}$ and Yenni Puspita Tanjung
}

Departement of Pharmacy, Akademi Farmasi Bumi Siliwangi

Jl. Rancabolang No. 104, Bandung, West Java 40286, Indonesia

*Correspondence: email: irahmairma12@gmail.com

Online Published: December 31, 2020

DOI : 10.20961/jkpk.v5i3.46746

\begin{abstract}
One of the manual brewing techniques is the pour-over V60 method. It uses a filter paper, which is suspected of containing chlorine as a paper bleaching agent that will dissolve in coffee. Health problems that can be caused by consuming chlorine-containing beverages in the long term can cause directly disease related to liver, bladder, intestinal cancers, arteriosclerosis, high blood pressure, pneumonia, bronchitis, dyspnea, and allergies. This study aims to determine the chlorine content of brewed robusta coffee using the brew V60 method. The chlorine test with the colour reaction method and the precipitation test as qualitative analysis to determine chlorine levels is an argentometric titration with the Mohr method. This research shows that all three samples of filter paper and coffee with V60 brewing method contain chlorine. The titration result shows that chlorine levels in filter paper brand $A$ are $81.9 \mathrm{mg} / \mathrm{L}$, brand $B 49.9 \mathrm{mg} / \mathrm{L}$, and brand $C$ $69.9 \mathrm{mg} / \mathrm{L}$. Levels of chlorine in V60 brewed coffee brand A are $44.6 \mathrm{mg} / \mathrm{L}$, brand B $21.9 \mathrm{mg} / \mathrm{L}$, and brand $C 28.6 \mathrm{mg} / \mathrm{L}$. This research concludes that the chlorine content in filter paper and $\mathrm{V} 60$ coffee brewing beverages on brand $A$, brand $B$, and brand $C$ is unqualified according to WHO regulation about chlorine qualification for clean drinking water, which is $5 \mathrm{mg} / \mathrm{L}$.
\end{abstract}

Keywords: Chlorine analysis, robusta coffee, V60 brew method, argentometric titration.

\section{INTRODUCTION}

Coffee is a very popular beverage globally, and the third most commonly consumed after water and tea [1]. Coffee is the second most valuable product (besides crude oil) exported from developing countries, with a trading volume of around 22 billion US\$ [2]. Based on data from the International Coffee Organization (ICO), the level of coffee consumption in the world in 2018 to 2019 increased by about $2.1 \%$ to 164.84 million bags [3]. In Indonesia, coffee consumption in the last four years continued to increase by $20 \%$ with a total consumption of $1.15 \mathrm{~kg} /$ capita/year in 2016 [4].

Coffee contains complex chemicals that provide large amounts of chlorogenic acid and caffeine. Also, coffee has more than thousands of natural chemicals such as carbohydrates, lipids, nitrogen compounds, vitamins, minerals, alkaloids, and phenolic compounds, which are healthy [5]. Several benefits in consuming coffee have been widely studied, including antimicrobials [6], preventing several chronic and degenerative diseases, such as cancer, cardiovascular 
disorders, diabetes, and Parkinson's disease [7].

However, along with the increasing consumptive nature and changes in people's lifestyles, drinking coffee has become a lifestyle. The creative coffee shop industry is growing and developing so rapidly, and it is here to provide choices on how to enjoy coffee through good brewing with new methods.

The most popular brewing method is the pour-over, drip, or filtered method. The coffee brewing results' aroma and taste characteristics tend to be tastier, lighter, and clean (clean without pulp) the ground coffee has been filtered [8]. The V60 method is popular among coffee shops because it is relatively inexpensive and can optimize a balanced coffee's aroma and flavour characteristics and is certainly convenient for consumption [9].

V60 method uses filter paper suspected of containing chlorine as a paper bleaching agent that will dissolve in coffee brewed. Chlorine is essential to be used as a bleach in paper and clothing factories. Because it is disinfecting, large amounts of chlorine are hazardous.

According to $\mathrm{WHO}$, the chlorine limit requirements for drinking water quality requirements are below $5 \mathrm{mg} / \mathrm{L}$ [10]. Health problems that can be caused by consuming chlorine-containing drinks in the long term can cause lung diseases such as pneumonitis, shortness of breath, emphysema, and bronchitis [11]. Furthermore, it can be caused directly to liver, bladder, intestinal cancers, arteriosclerosis, high blood pressure, bronchitis, dyspnea, and allergies [12].

\section{METHODS}

\section{Materials and Instrumentation}

The tools used in this study include Hario V60 ceramic coffee dripper (Hario Co., Ltd. Indonesia). Materials used include filter paper $\mathrm{A}, \mathrm{B}$, and $\mathrm{C}$, robusta coffee powder (local suppliers, Indonesia), aqua dest, silver nitrate (Merck), nitric acid 65\% (Merck), starch, potassium iodide (Merck), potassium chromate (Merck), sodium chloride (Merck), and hydrochloric acid 37\% (Merck).

\section{Research Methods}

The method used in this research is the experimental method, with iodine test, precipitation test, and Argentometric Mohr Titration for chlorine analysis in the filter paper and brew robusta coffee with V60 coffee dripper.

\section{a. Sample Preparation}

Hario V60 coffee brewing equipment is used to brew robusta coffee. Materials used include filter paper of brand $\mathrm{A}, \mathrm{B}$, and $\mathrm{C}$ and Indonesian robusta ground coffee from local suppliers. First, filter paper samples are prepared and folded with a cone shape, then inserted using Hario V60. Pour $92^{\circ} \mathrm{C}$ hot water in a circular motion, let it be for 5 minutes the brewed water used as a filter paper sample.

The coffee brewing sample is prepared by folding filter paper with a cone shape, then arranged into Hario V60 equipment. Pour hot water on filter paper to avoid the scent of paper mixed with coffee and make sure that V60 and the container are hot. Prepared coffee to be brewed, with a ratio of 1:15 (1 gram coffee with $15 \mathrm{~mL}$ of water) put coffee 
into filter paper. Pour about 50-60 mL full hot water in a circular motion and let it be for about 30-40 seconds, this process aims to wet coffee, and coffee will expand or be called a blooming. For maximum brewed results, in every movement of one circle, leave it until the water is poured on the bottom of the coffee [13].

\section{b. Qualitative Analysis of Chlorine}

The colour reaction test, about $2 \mathrm{~mL}$ filter paper, and a brewed coffee samples were put into a test tube and added three drops of $3 \%$ amylum solution and 3-5 drops of $10 \%$ potassium iodide solution. A deposition test was then carried out by taking $2 \mathrm{~mL}$ of sample and putting it in a test tube. Added $1 \mathrm{~mL}$ solution of $3 \mathrm{~N} \mathrm{HNO}_{3}$, then heated for 2-3 minutes. While still hot, add five drops of $5 \% \mathrm{AgNO}_{3}$ solution.

\section{c. Argentometric Titration}

Argentometric titration is performed to determine the amount of chlorine present in filter paper and brew coffee. The procedure begins with the standardization of $\mathrm{AgNO}_{3}$ solution with $\mathrm{NaCl}$, by taking $25 \mathrm{~mL}$ of $0.01 \mathrm{~N}$ $\mathrm{NaCl}$ solution, placed in Erlenmeyer, and added about $1 \mathrm{~mL}$ of $5 \% \mathrm{~K}_{2} \mathrm{Cr}_{2} \mathrm{O}_{4}$ indicator solution. Titrated until the colour changes to brownish red. Titration was performed three times, and $\mathrm{AgNO}_{3}$ normality was calculated. Then the titration on filter paper and coffee brewing samples, with each $100 \mathrm{~mL}$ sample, is put into Erlenmeyer, then added as much $\begin{array}{lllll}1 \mathrm{~mL} & \text { of } 5 \% & \mathrm{~K}_{2} \mathrm{Cr}_{2} \mathrm{O}_{4} & \text { indicator solution. }\end{array}$ Titrated with $\mathrm{AgNO}_{3} 0.01 \mathrm{~N}$ standardized and repeated replication three times in each sample [14].

\section{d. Statistical Data Analysis}

The experimental design of chlorine determination on filter paper and robusta coffee shows all measurements and analyses were in triplicate. Analysis of variance using one way ANOVA. The results with $p<0.05$ were regarded to be statistically significant.

\section{RESULTS AND DISCUSSION}

\section{Qualitative Analysis of Chlorine}

Brewing robusta coffee with the V60 method, which has an angle of $60^{\circ}$ and a special groove pattern created to regulate the rate of water into an appropriate collaboration to optimize the characteristics of balanced aroma and flavours certainly convenient for consumption [15]. The chlorine in the filter paper is obtained from the bleaching process and can be streamed into Robusta coffee brewed using the V60 method.

Chlorine content on filter paper and brewed robusta coffee was examined using a colour reaction method and precipitation test as a qualitative analysis. The colour reaction test is done by adding a starch solution and potassium iodide solution. The result is all of the samples filter paper and brewed robusta coffee with V60 method gives a purplish-blue colour. The precipitation test is done by adding nitric acid and silver nitrate and give white precipitation for all samples. Both samples, filter paper, and brewed coffee with three different filter paper ( $A, B$, and $C$ ) result from qualitative analysis (Table 1).

Based on the results in Table 1, there were colour reactions with the iodine test and precipitation test. All samples turn purplishblue on the colour reaction test, indicating 
chlorine on filter paper and brewed coffee. The purplish-blue colour is produced due to triiodide ions (Equation 1 and 2) [16].

Starch forms a very dark blue complex with triiodide. It is thought that the iodine-iodide mixture combines with the starch to form an infinite polyiodide homopolymer. This was rationalized through single-crystal $\mathrm{x}$-ray crystallography and comparative Raman spectroscopy. Amylose on starch is the compound that is responsible for the blue colour. Its chain forms a helix shape, and iodine can be bound inside this helix [17].

$\mathrm{Ag}^{+}(a q)+\mathrm{Cl}(a q) \rightleftharpoons \mathrm{AgCl}(s)$
In the precipitation test, there were white precipitate on each filter paper and brewed coffee of brands $A, B$, and $C$ which was tested by the addition of nitric acid $\left(\mathrm{HNO}_{3}\right)$ and silver nitrate $\left(\mathrm{AgNO}_{3}\right)$ solutions. Silver nitrate will precipitate chloride ion $\left(\mathrm{Cl}^{-}\right)$ as silver chloride $(\mathrm{AgCl})$, the reaction on equation 3 , this called precipitation reaction [18].

\section{Determination of Chlorine Content}

To determine the chlorine content using argentometric titration using the Mohr method. Because this method produces a fast reaction, the colour at the endpoint of the titration is sharp. So it is very suitable for chlorine analysis in dark brewed coffee.

Table 1. Analysis of chlorine on filter paper and brewed coffee

\begin{tabular}{|c|c|c|c|c|c|}
\hline \multirow[b]{2}{*}{ Sample* } & \multicolumn{2}{|c|}{$\begin{array}{c}\text { Qualitative analysis of } \\
\text { chlorine }\end{array}$} & \multicolumn{2}{|c|}{ Argentometric titration } & \multirow{2}{*}{$\begin{array}{l}\text { WHO regulation o } \\
\text { chlorine content in } \\
\text { drinking water } \\
(<5 \mathrm{mg} / \mathrm{L})\end{array}$} \\
\hline & $\begin{array}{c}\text { Colour } \\
\text { reaction } \\
\text { test }\end{array}$ & $\begin{array}{c}\text { Precipitation } \\
\text { test }\end{array}$ & $\begin{array}{l}\text { Volume of } \mathrm{AgNO}_{3} \\
\text { average }(\mathrm{mL})\end{array}$ & $\begin{array}{c}\text { Chlorine } \\
\text { content (mg/L) }\end{array}$ & \\
\hline FP A & + & + & 12.3 & 81.9 & unqualified \\
\hline FP B & + & + & 7.5 & 49.9 & unqualified \\
\hline FP C & + & + & 10.5 & 69.9 & unqualified \\
\hline$B C A$ & + & + & 6.7 & 44.6 & unqualified \\
\hline $\mathrm{BC} B$ & + & + & 3.3 & 21.9 & unqualified \\
\hline $\mathrm{BC} C$ & + & + & 4.3 & 28.6 & unqualified \\
\hline
\end{tabular}

${ }^{*} \mathrm{FP}$ for filter paper and BC for brewed coffee; ${ }^{* *}(+)$ for positive purplish-blue and white precipitation;

$$
\begin{aligned}
& \mathrm{ClO}_{2}(a q)+5 \mathrm{I}^{-}(a q)+4 \mathrm{H}^{+}(a q) \rightarrow \mathrm{Cl}(a q)+2,5 \mathrm{I}_{2}(a q)+2 \mathrm{H}_{2} \mathrm{O}(n) \\
& \mathrm{I}_{2}(a q)+\mathrm{I}^{-}(a q) \rightarrow \mathrm{I}_{3}{ }^{-}(a q)
\end{aligned}
$$

The argentometric titration of chlorine analysis on brewed robusta coffee in this study used the Mohr method, which is analyzed using silver ions on silver nitrate with $\mathrm{K}_{2} \mathrm{Cr}_{2} \mathrm{O}_{4}$ indicator solution and until the colour changes to brownish red. The titration result shows that chlorine levels in filter paper brand $A$ are $81.9 \mathrm{mg} / \mathrm{L}$, brand B $49.9 \mathrm{mg} / \mathrm{L}$, and brand C $69.9 \mathrm{mg} / \mathrm{L}$. Levels of chlorine in V60 brewed coffee brand $A$ are $44.6 \mathrm{mg} / \mathrm{L}$, brand $B 21.9 \mathrm{mg} / \mathrm{L}$, and brand $C 28.6 \mathrm{mg} / \mathrm{L}$ (Table 1).

The result of chlorine content on filter paper $\mathrm{A}, \mathrm{B}$, and $\mathrm{C}$ compared with chlorine on brewed robusta coffee, was performed using oneway Anova. The results with $p<0.05$ were 
regarded to be statistically significant differences (Figure 1). The highest chlorine content is filter paper A (FPA), which is 81.9 $\mathrm{mg} / \mathrm{L}$. This affects the amount of chlorine content in brewed coffee A (BCA), $44.6 \mathrm{mg} / \mathrm{L}$. Furthermore, the smallest chlorine content is filter paper B (FPB), which is $49.9 \mathrm{mg} / \mathrm{L}$ and $21.9 \mathrm{mg} / \mathrm{L}$ for brewed coffee $B(B C B)$.

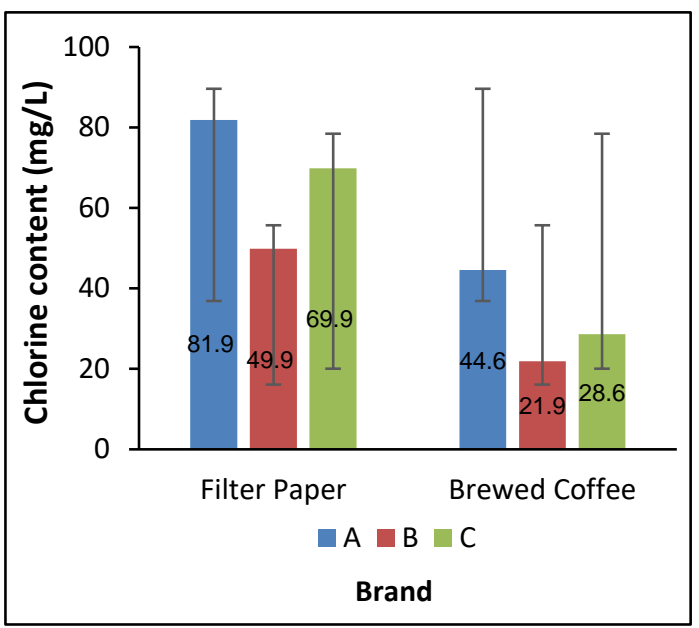

Figure 1. Comparison chlorine content on filter paper and brewed coffee with different brands, with $p<0.05$

This result shows that the higher the chlorine concentration on the filter paper, the greater chlorine dissolved in the brewed coffee. This is following other research regarding paper whitening agent (chlorine) found in tea bags, precisely in tea bags made of paper will also be dissolved in tea brewing $[11,19]$. That can be caused by the solubility of a substance and temperature of the water. Chlorine properties that are soluble in water, the higher the degree of water used for brewing, the higher the chlorine content in the brewed coffee.

The chlorine content in filter paper comes from the pulp production process in the paper bleaching process with chlorination and paper oxidation methods using calcium or sodium hypochlorite [20]. Several studies have tried to replace paper bleaching agents in the bleaching process, replacing chlorine bleach with chlorine dioxide [21]. Furthermore, the results are the formation of chlorinated dioxins and furans at the level of ecosystem background, food, soil and air, and unbleached pulp, bleached pulp, paper, and fiber products.

\section{CONCLUSION}

This research concludes that the chlorine content in filter paper and V60 coffee brewing beverages on brand $\mathrm{A}$, brand $\mathrm{B}$, and brand $C$ is unqualified according to $\mathrm{WHO}$ regulation about chlorine qualification for clean drinking water, which is $5 \mathrm{mg} / \mathrm{L}$. Furthermore, people need to replace the alternative filter paper containing bleach using filter paper that does not use bleach or can also use a cloth to filter brewed coffee.

\section{ACKNOWLEDGMENT}

The authors would like to thank the Ministry of Research and Technology/ National Research and Innovation for supporting this research under Research Grants for Beginner Lecturers (Hibah Penelitian Dosen Pemula) programs.

\section{REFERENCES}

[1] C. E. Mills, M. J. Oruna-Concha, D. S. Mottram, G. R. Gibson, and J. P. E. Spencer, "The effect of processing on chlorogenic acid content of commercially available coffee," Food Chem., vol. 141, no. 3, pp. 3335-3340, 2013.

DOI: 10.1016/j.foodchem.2013.06.014 
[2] K. G. Motora and T. T. Beyene, "Determination of Caffeine in Raw and Roasted Coffee Beans of Ilu Abba Bora Zone, South West Ethiopia," Indo Am. J. Pharm. Res., pp. 463-470, 2017. DOI: 10.5281/zenodo.1036324

[3] International Coffee Organization, "International Coffee Organization Coffee Market Report: July 2019," 2019.

Google Scholar

[4] Asosiasi Eksportir Indonesia, "Indonesian Coffee Exporters and Industry Association: Consumption of Indonesian Coffee," 2017.

Google Scholar

[5] H. Lire Wachamo, "Review on Health Benefit and Risk of Coffee Consumption," Med. Aromat. Plants, vol. 6, no. 4, pp. 1-12, 2017.

DOI: 10.4172/2167-0412.1000301

[6] U. Mueller, T. Sauer, I. Weigel, R. Pichner, and $M$. Pischetsrieder, "Identification of $\mathrm{H}_{2} \mathrm{O}_{2}$ as a major antimicrobial component in coffee," Food Funct., pp. 65-272, 2011.

DOI: 10.1039/c0fo00180e

[7] I. A. Ludwig, M. N. Clifford, M. E. J. Lean, H. Ashihara, and A. Crozier, "Coffee: Biochemistry and potential impact on health," Food and Function. vol. 5, no. 8, pp. 1695-1717, 2014. DOI: $10.1039 / \mathrm{c} 4$ fo $00042 \mathrm{k}$

[8] B. Phrommarat, "Life cycle assessment of ground coffee and comparison of different brewing methods: A case study of organic arabica coffee in Northern Thailand," Environ. Nat. Resour. J., vo. 17, no. 2, pp. 96-108, 2019.

DOI: 10.32526/ennrj.17.2.2019.16

[9] Otten, "V60 Hario - Alat Seduh Kopi Pour Over untuk Seduhan Kopi Terbaik," pp. 25-30, 2014.

Google Scholar

[10] World Health Organization, World Health Organization, Guidelines for drinking-water quality, 4th edition, incorporating the 1 st addendum. World Health Organization, 2017.

Google Scholar
[11] S. Wansi and S. Wael, "Analisis Kadar Klorin Pada Teh Celup Berdasarkan Waktu Seduhan," Biopendix J. Biol. Pendidik. dan Terap., vol. 1, no. 1, pp. 24-31, 2014.

DOl: 10.30598/biopendixvol1 issue1page22-31

[12] I. H. Mohsen, A. H. Mohsen, and H. K. Zaidan, "Health effects of chlorinated water: A review article," Pakistan J. Biotechnol., vol. 16, no. 3, pp. 163-167, 2019.

DOI: 10.34016/pjbt.2019.16.3.24

[13] N. Z. Rao and M. Fuller, "Acidity and Antioxidant Activity of Cold Brew Coffee," Sci. Rep., vol. 8, no.1, pp. 19, 2018.

DOI: 10.1038/s41598-018-34392-w

[14] M. Shukla and S. Arya, "Determination Of Chloride Ion(Cl-) Concentration In Ganga River Water By Mohr Method At Kanpur, India," Green Chem. Technol. Lett., vol. 4, no. 1, pp. 6-8, 2018. DOI: $10.18510 / \mathrm{gctl} .2018 .412$

[15] M. Yuliandri, Seduh: Seni Meracik Kopi. Jakarta: Penerbit SEEIS.co., 2018.

ISBN: 9786026036506

[16] N. Li, L. Shi, X. Wang, F. Guo, and C. Yan, "Experimental Study of Closed System in the Chlorine Dioxide-lodideSulfuric Acid Reaction by UV-Vis Spectrophotometric Method," Int. J. Anal. Chem., vol. 2011, pp. 1-7, 2011. DOI: $10.1155 / 2011 / 130102$

[17] S. Madhu, H. A. Evans, V. DoanNguyen, J. G. Labram, G. Wu, M. L. Chabinyc, R. Seshadri, and F. Wudl, "Infinite Polyiodide Chains in the Pyrroloperylene-lodine Complex: Insights into the Starch-lodine and Perylene-lodine Complexes," Angew. Chemie Int. Ed., vol. 55, no. 28, pp. 8032-8035, Jul. 2016.

DOI: 10.1002/anie.201601585

[18] R. Chang and J. Overby, "General Chemistry The Essential Concepts," Sixth Ed., 2011. Google Scholar

[19] P. Hermiyanti, F. Rokhmalia, and $\mathrm{H}$. Suryono, "Chlorine Minimization Of 
Tea Bag Steeping Through Determining Drinking Water Content, Duration, And Steeping Temperature," Proc. Int. Conf. Heal. Politech. Surabaya, pp. 556-558, 2016 Google Scholar

[20] A. K. Singh and R. Chandra, "Pollutants released from the pulp paper industry: Aquatic toxicity and their health hazards," Aquatic Toxicology. vol. 211, pp. 202-216, 2019.

DOI: 10.1016/j.aquatox.2019.04.007

[21] P. Axegård, "The effect of the transition from elemental chlorine bleaching to chlorine dioxide bleaching in the pulp industry on the formation of PCDD/Fs," Chemosphere. vol. 236, 2019.

DOI: 10.1016/j.chemosphere.2019.124386 